\title{
36. COMPARISON OF WINTER AND SUMMER GROWTH STAGES OF THE DIATOM EUCAMPIA ANTARCTICA FROM THE KERGUELEN PLATEAU AND SOUTH OF THE ANTARCTIC CONVERGENCE ZONE ${ }^{1}$
}

\author{
Greta A. Fryxell ${ }^{2}$
}

\begin{abstract}
On ODP Leg 119, specimens collected of Eucampia antarctica (Castracane) Mangin var. antarctica exhibited morphological and distribution patterns that contrasted with those of Eucampia antarctica var. recta (Mangin) G. Fryxell et Prasad. E. antarctica var. antarctica was found over the northern Kerguelen Plateau, north of the summer Antarctic Convergence Zone, in the subpolar plankton and in the sediments. E. antarctica var. recta was found close to the continent in Prydz Bay. It was also collected near and under the ice in the northern Weddell Sea on a National Science Foundation Division of Polar Programs project (1983-1988).

A key feature for distinguishing the two varieties in the field is the growth habit, with curvature in broad girdle view of the nominate, subpolar variety in both the winter stage and the more lightly silicified summer stage. A low ratio of terminal to intercalary valves results from the repeated division of the original doublets into chains of considerable length of the winter stage. Small spines around the elevations of one valve serve to clasp the sibling valve and maintain the chain formation. Cells of $E$. antarctica var. recta tend to be somewhat larger than $E$. antarctica var. antarctica, and they form chains that are straight in broad girdle view but slightly curved in narrow girdle view. There are no spines on an elevation of the valve, and a hyaline ring surrounds the pore field, forming a costate ocellus in the winter.

This truly polar variety shows less growth in the winter stage, with a higher ratio of terminal to intercalary valves in Prydz Bay than that of the nominate variety from the subpolar regions over the Kerguelen Plateau.
\end{abstract}

\section{INTRODUCTION}

Biological oceanographic components aboard JOIDES Resolution as well as on the service vessel, Maersk Master, allowed sampling of living plankton from Prydz Bay and over the Kerguelen Plateau for comparison with plankton from Holocene sediments. Although Eucampia antarctica (Castracane) Mangin var. recta was found in small numbers in the Prydz Bay phytoplankton $(<1 \%$, with $0.3 \%$ maximum; Kang, 1989) and in sediments (about $0.3 \%$ of the surface Prydz Bay sediment assemblage; G. A. Fryxell, unpubl. data), it is better represented in net plankton samples. Heavily silicified and commonly well preserved in older material, it can be used to understand ecological conditions at the time of growth.

Eucampia antarctica has a complex nomenclatural history, summarized in Fryxell et al. (1989), whose usage will be followed here. Morphological differences were noted between the nominate variety and Eucampia antarctica var. recta (Mangin) G. Fryxell et Prasad, the ice-edge variety found in the northern Weddell Sea during the Antarctic Marine Ecosystem Research at the Ice Edge Zone (AMERIEZ) program (Fryxell and Prasad, 1990). From shipboard examination, these authors also showed that $E$. antarctica var. recta does not produce resting spores, but instead has a specialized winter growth stage; from reported occurrences they considered that the same process takes place in $E$. antarctica var. antarctica farther north. The present work tests this idea and clarifies the apparent anomalies in previously reported distribution patterns by utilizing both planktonic and sedimentary samples from Ocean Drilling Program (ODP) Leg 119 in the southern Indian Ocean.

\footnotetext{
${ }^{1}$ Barron, J., Larsen, B., et al., 1991. Proc. ODP, Sci. Results, 119: College Station, TX (Ocean Drilling Program).

2 Department of Oceanography, Texas A\&M University, College Station, TX 77843-3146, U.S.A.
}

\section{Reported Distribution in the Plankton}

Hustedt (1958) reported that he found $E$. antarctica from the plankton in Salpa fusiformis (but not Salpa confoederata) and widely distributed in Antarctic and Subantarctic waters from the southern Atlantic and southern Indian oceans. As part of the investigations of the Brategg Expedition in the southern Pacific, Hasle (1969) classified it with her "Group 7" species that were found in the open ocean throughout the Antarctic area, adding that $E$. antarctica was not found outside the Southern Ocean. She observed that the maximum populations shifted from the Subantarctic Zone to the Antarctic Zone during that survey (13 December 1947-26 February 1948). However, Fenner et al. (1976) found it more common late in the season in the plankton of the Subantarctic Zone than in the Antarctic waters of the eastern Pacific Ocean (2 February-30 March 1974). Adding their work to that of Hasle (1969), Fenner et al. (1976) calculated that from estimated mean values, E. antarctica made up the greatest percentage of the total diatom assemblage (about $2 \%$; fig. 10 in Fenner et al., 1976) at $60^{\circ} \mathrm{S}$, typically near the Antarctic Convergence Zone (ACZ) at that longitude.

There is a dichotomy in these observations of its distribution in the plankton, with others finding Eucampia to be a neritic species. From centrifuged samples taken on the $O b$ and averaged over long distances (a method that tends to include a species that is present in patches and/or small numbers), Kozlova (1966) did not find Eucampia north of the ACZ in the plankton. She considered it among the Antarctic neritic diatoms, making up between $0.1 \%$ and $0.5 \%$ of the plankton over a wide latitudinal band in the southern Indian Ocean and in greater relative abundance $(0.3 \%-8.3 \%)$ closer to the Antarctic coast. Hargraves (1968) agreed that it was mostly confined to Antarctic regions in the plankton from Eltanin Cruises 10-15 (mostly in the southern Pacific, October 1963 to December 1964). He found sporadic occurrences of it in the Subantarctic Zone, associated with temperatures of $-1.5^{\circ}$ to $6.2^{\circ} \mathrm{C}$, but usually $<4^{\circ} \mathrm{C}$. In addition, Krebs $(1977,1983)$ reported it present in the inshore 
plankton every month except August, mostly from Arthur Harbor, Anvers Island, Antarctica.

\section{Reported Distribution in the Sediments}

A similar dichotomy of observations of distribution is found in paleontological accounts. In the temperate south Atlantic, Fenner (1977) noted with astonishment the common presence of E. antarctica, along with another Antarctic diatom, Actinocyclus actinochilus (Ehrenberg) Simonsen, probably of Pleistocene age, from the northeastern Argentine Basin (Deep Sea Drilling Project Leg 39 , Site $358,37^{\circ} 39.1^{\prime} \mathrm{S}, 35^{\circ} 57.82^{\prime} \mathrm{W}$, in $5000 \mathrm{~m}$ water depth). Based on the assumption that Eucampia originated in the ice, or in waters adjacent to the ice, Burckle and Stanton (1975) considered that the distribution in surface sediments of the Argentine Basin resulted from transport by Antarctic Bottom Water (AABW). DeFelice and Wise (1981) found $E$. antarctica common in the sediment cores in the South Atlantic from the Agulhas Basin area to the Antarctic continental shelf, both north and south of the ACZ, associated with winnowed deposits. Abbott (1974) found it abundantly throughout the Subantarctic in the southeast Indian Ocean.

Kozlova (1966) considered $E$. antarctica to be an indicator species in sediments of Antarctic waters, better preserved than many planktonic species and more abundant over the continental shelf. Gombos (1974) at first proposed that it could be used in the geologic record as an indicator in tracing the movement of the ice front; Schrader (1976) agreed and found it in highest abundance close to the Antarctic ice sheet. However, in the light of the findings of Fenner et al. (1976) that it was most abundant in the plankton north of the ACZ, Gombos (1976) concluded that this species must reach its maximum abundance independent of the ice association. Burckle (1984) summarized the published accounts of the distribution of $E$. antarctica from both the water column and the sediments and concluded that it was in greatest abundance either near shore or in the habitat provided by floating ice, citing an observation by Gombos of $\mathrm{Eu}$ campia accounting for nearly $80 \%$ of a plankton collection taken near an iceberg melting in the seawater.

\section{METHODS AND MATERIALS}

During the austral summer, the plankton was sampled from sites over the Kerguelen Plateau and south across the ACZ into Prydz Bay, Antarctica. At the northern sites, a hand-held $20-\mu \mathrm{m}$ net was used to sample the effluent from the thrusters of the ship. In Prydz Bay, 35- $\mu$ m opening and closing nets were used for vertical hauls and horizontal tows. In addition, samples were used from the AMERIEZ program, as summarized in Fryxell and Prasad (1990), and from collections of S. Z. El-Sayed.

Samples from the mud line or near the sediment/water interface were analyzed for this study to compare with the Holocene sediment record and treated as in Battarbee (1973). They were examined on board ship in water and Hyrax mounts and in a shorebased study in Hyrax mounts. Light and scanning electron microscopy (SEM) in the latter study used Zeiss Standard 18 upright and Zeiss 405-ICM inverted light microscopes and the Jeolco JSM-35 and JSM-25 and Jeolco T330A SEM instruments.

\section{RESULTS}

\section{Morphology of Subpolar and Polar Winter Stages}

Eucampia antarctica var. antarctica forms spiraling chains in the winter growth stage, with the curvature resulting from the asymmetry of the valves (Pl. 1, Figs. 1 and 2). The margins of the valves lie in one plane, and the two valves of a cell are joined together at the girdle before the division stage. However, the mature epitheca has a set of delicate, scalelike bands that overlap the hypotheca (Pl. 1, Fig. 1), as Semina (1982) thought pos- sible. The chains are held together by organic material and possibly interdigitating ridges of pore fields on elevations of differing height (Pl. 1, Figs. 2B and 3). Areolae extend onto the elevations without a heavily silicified ring or ocellus surrounding the pore field. Small, flattened spines from the area around the pore field serve to brace the elevations on the sibling valves against forces parallel to the valvar plane (Pl. 1, Figs. 2A and 2B). The areolae are irregular in appearance, but rows radiate from the slit of the eccentric labiate process that is located about five areolae from the nearest margin in ventral view (Pl. 1, Fig. 4). The delicate cribra are located at midlevel of the heavy basal siliceous membrane and are connected to it by radial threads, contrasting sharply with that more solid structure (Pl. 1, Figs. 2B and 4) but similar to that described for the $\mathrm{Cy}$ matosiraceae in Hasle et al. (1983, p. 77).

In summary, the winter growth stage of the subpolar, nominate variety is more or less asymmetrical in broad girdle view with the two elevations on a valve usually of differing heights, spines around the pore fields, and irregular cribra sunk into the areolae (Pl. 2, Figs. 1, 2A, and 2B). There are some different features on the intercalary valves from chains of Eucampia antarctica var. recta from Prydz Bay also figured, for example, in Ehrenberg (1844; figs. 8A and 8B) from the Sud-Pol-Reise (18411843); Steyaert and Bailleux (1975; figs. 10-21) from the Breid Bay, Antarctica, collections of the 1964-1966 Belgo-Dutch Expedition; and Fryxell (1989; figs. 24-26) and Fryxell and Prasad (1990) from the Weddell Sea. This polar variety is more symmetrical in broad girdle view with elevations of similar heights, has a thickened ring of silica around the pore fields forming a costate ocellus (Syvertsen and Hasle, 1983; Sims, 1986), and has cribra with a sublinear pattern of pores (Pl. 2, Figs. 3 and 4; Fryxell and Prasad, 1990). Both the subpolar and polar varieties have heavily silicified valves with relatively straight margins, areolae in an irregular pattern radiating from the single labiate process on each valve, and the slitlike external opening of the labiate process located about five areolae from the nearest margin in ventral view.

The terminal valves of the original winter stage doublets of $E$. antarctica have pointed elevations without pore fields (Ross et al., 1977); thus far these valves of the two varieties cannot be differentiated. They result from an unequal nuclear division and are not restrained by an adjacent elevation of a sibling valve. These are common in the Weddell Sea plankton (Fryxell and Prasad, 1990) and in Prydz Bay sediments, but are rarer in Kerguelen sediments (Table 1) or in that plankton.

\section{Morphology of Subpolar and Polar Summer Stages}

Like the winter growth stage, the cells of the summer vegetative stage of $E$. antarctica var. antarctica also form long, spiraling chains, with both the valves and the bands involved in the asymmetry seen in the broad girdle view (Pl. 3, Fig. 1; Fryxell, 1989, fig. 23). The margins are in one plane (Pl. 3, Figs. 1, 2, and 5), as in the winter form. The bands are delicate, but some can be resolved in SEM (Pl. 3, Figs. 1, 2, and 4). They form a part of the height of the vegetative cell, and during vegetative reproduction the forming valves are not attached to the parent valves, but are inside the multiple bands from the epitheca and maturing hypotheca (PI. 3, Fig. 1). The cells are held together by organic material from the pore field on the elevations, again bounded by spines. In one case, a spurious row of spines developed farther down the elevation, and from this position it can be seen how they are produced from the walls between the areolae (Pl. 3, Fig. 3). The slitlike external opening of the single labiate process is much closer to the margin on the ventral side than it is in the winter stage, only about two areolae from the nearest margin (Pl. 3, Figs. 4 and 5). The cribra are similar to those in the winter stage, a delicate and irregular webbing attached to 
Table 1. Comparison of terminal and intercalary Eucampia valves from northern Kerguelen Leg 119 sites with those of mud-line sediments from Prydz Bay.

\begin{tabular}{l}
\hline \multicolumn{1}{c}{$\begin{array}{c}\text { Core, section, } \\
\text { interval }(\mathrm{cm})\end{array}$} \\
$\begin{array}{l}\text { E. antarctica var. antarctica, } \\
\text { northern Kerguelen Plateau }\end{array}$ \\
119-736A-
\end{tabular}

$\begin{array}{lrr}1 \mathrm{H}-1,30-32 & 0 & 100 \\ 1 \mathrm{H}-1,139-142 & 3 & 97\end{array}$

$119-736 \mathrm{~B}-$

$\begin{array}{llr}1 \mathrm{H}-2,35-37 & 1 & 99 \\ 1 \mathrm{H}-1,85-87 & 0 & 100 \\ 1 \mathrm{H}-1,135-137 & 0 & 100\end{array}$

119-737A

\begin{tabular}{lrr}
$1 \mathrm{H}-1,40-42$ & 0 & 47 \\
$1 \mathrm{H}-1,90-92$ & 2 & 28 \\
\cline { 2 - 3 } Total & 6 & 571
\end{tabular}

E. anfarctica var. recta, Prydz Bay

119-740B-

1R-1 (mud line)

\begin{tabular}{crr} 
Slide 1 & 45 & 99 \\
Slide 2 & 33 & 80 \\
Slide 3 & 9 & 33 \\
Slide 4 & 18 & 35 \\
Slide 5 & 22 & 50 \\
Slide 6 & 50 & 84 \\
Total & $\underline{177}$ & 381 \\
\hline
\end{tabular}

the basal siliceous membrane by radial threads (Pl. 3, Figs. 3 and 4).

In summary, in the summer vegetative stage the cell $E$. antarctica var. antarctica is asymmetrical in broad girdle view, has margins lying in one plane, and has spines interrupting the continuity of areolae on the elevations approaching the pore field (Pl. 4, Figs. 1-3). In contrast, the summer vegetative stage of $E$. antarctica var. recta from Prydz Bay and Weddell Sea plankton is symmetrical in broad girdle view with elevations of equal height and has a margin that rises in a bipolar pattern under each elevation, areolae on the elevations continuously to the pore fields at their terminus with no spines, and delicate, but well-organized, cribra in the areolae of the basal siliceous membrane (Pl. 4, Figs. 4 and 5). The two varieties are similar in that the single labiate process of the summer vegetative stage is located two areolae from the closest margin, the areolae are more rectangular than those of the winter stage, and the bands surround a major portion of the volume of the cells.

\section{Size Relationships}

The winter stages of the two varieties are preserved in the surface sediments of both the Kerguelen Plateau and Prydz Bay. Their observed size ranges are given in Table 2 . The average length of the bipolar valves in broad girdle view from the Kerguelen Plateau is $38.3 \mu \mathrm{m}$ (s.e. $=1.6$ ), with more than half of the valves between 27 and $47 \mu \mathrm{m}$, in a distribution approaching a normal curve (Fig. 1A). The average valve length from Prydz Bay is $55.1 \mu \mathrm{m}($ s.e. $=2.7)$, with more than half of the valves between 32 and $57 \mu \mathrm{m}$, in a more skewed curve (Fig. 1B). In general, those seen from Kerguelen area tend to be smaller in broad girdle view than those of $E$. antarctica var. recta, although the
Table 2. Comparison of winter stages of Eucampia antarctica.

\begin{tabular}{|c|c|c|}
\hline \multirow[b]{2}{*}{ Variety } & \multicolumn{2}{|c|}{ Eucampia antarctica } \\
\hline & var. antarctica & var. recta \\
\hline Length, broad girdle view ( $\mu \mathrm{m})$ & $13.5-88$ & $22.5-126$ \\
\hline Areolae in $10 \mu \mathrm{m}$ & $3-6$ & $4-5$ \\
\hline Growth habit, broad girdle view & Spiraling & Straight \\
\hline Spines on elevation & Present & Lacking \\
\hline${ }^{\mathrm{a}}$ Valve antiligula & Absent & Present \\
\hline
\end{tabular}

a As discussed in Fryxell and Prasad (1990).

A

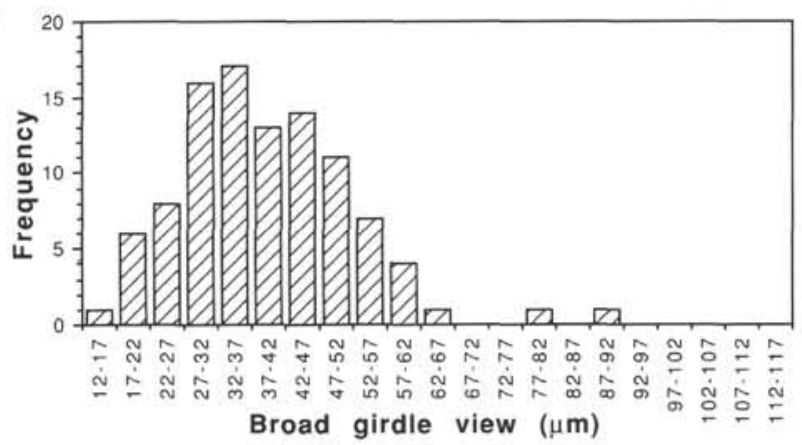

B

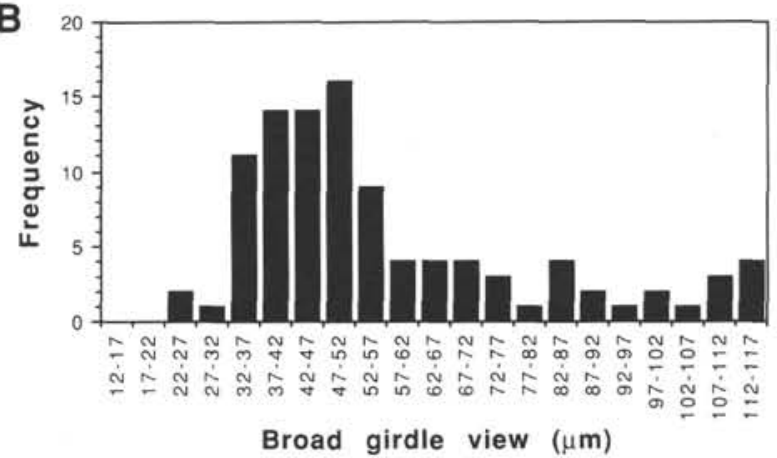

C

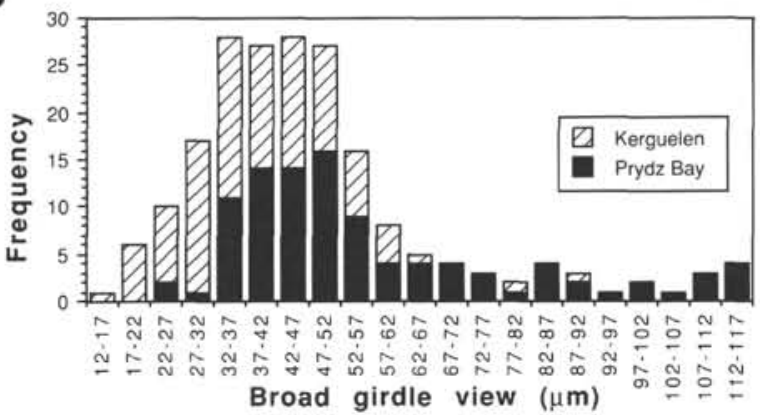

Figure 1. Frequency of sizes of valves from surface sediments from northern and southern sites. A. Northern Kerguelen sites $(n=100)$. B. Prydz Bay sites $(n=100)$. C. Stacked bar graph of northern and southern sites.

total ranges overlap and, if added together, appear to intergrade (Fig. 1C).

An effort was made to find the relationship, if any, of the broad girdle view of the bipolar valves (length) to the narrow girdle view (width) by measuring the valve view orientation. The scatter plot of the results shows less than $100 \%$ variation in the width of the narrow girdle view and very little, if any, correla- 
tion within one geographical area with the dimension of the broad girdle view, which increases by an order of magnitude (Fig. 2). Although the smallest lengths are from $E$. antarctica var. antarctica and the largest from E. antarctica var. recta, together they appear to form a continuum. The average width of the valves is $17.0 \mu \mathrm{m}$ (s.e. $=0.29$ ) for the subpolar variety and $19.6 \mu \mathrm{m}$ (s.e. $=0.37$ ) for the polar variety.

Because there is little correlation of valve width to valve length within one variety, cell volumes were estimated from broad girdle view measurements, using average widths as previously detailed (Fig. 3). Each valve (one-half cell) was considered as a three-dimensional ellipsoidal structure, topped by two cylindrical elevations. Within one variety, the valves with longer polar lengths have the greater volumes, in spite of shorter pervalvar heights. Cell volumes calculated from Kerguelen Plateau have an average of $15,200 \times 10^{3} \mu \mathrm{m}^{3}$ (s.e. $=786$; Fig. $3 \mathrm{~A}$ ), whereas those from Prydz Bay have average cell volumes of $30,300 \times$ $10^{3} \mu \mathrm{m}^{3}$ (s.e. = 1820; Fig. 3B). Once again, when put together, the two distributions form what appears to be a continuum (Fig. 3C).

Because the unequal heights of the elevations on single valves in E. antarctica var. antarctica was a feature useful in field samples, measurements were taken in both the Prydz Bay and Kerguelen samples for comparison (Fig. 4). Most of the Prydz Bay valves had small differences $($ mean $=1.08 \mu \mathrm{m}$, s.e. $=0.365$; Fig. 4A), whereas valves from the Kerguelen sample had a more even distribution $($ mean $=3.19 \mu \mathrm{m}$, s.e. $=0.401$; Fig. 4B). Together, they make an apparent continuum (Fig. 4C).

\section{DISCUSSION}

Eucampia antarctica has not been a dominant organism in most collections. In Prydz Bay phytoplankton, Kang and Fryxell (this volume) estimated that its integrated abundance in water columns (under $1 \mathrm{~m}^{2}$ ) from the five sites varied between $2.08 \times 10^{7}$ and $9.23 \times 10^{8}$ per square meter. Kang (1989) found sporadic abundance with depth, with a subsurface maximum between 5000 and 10,000 cells/L. Steyaert (1973) found it in smaller numbers with a maximum of 1730 cells/L at the surface in January $1967\left(70^{\circ} 01^{\prime} \mathrm{S}, 25^{\circ} 18^{\prime} \mathrm{E}\right)$. The winter stage is even less abundant, with $<100$ cells/L found in July in the Weddell Sea, present as full (living) cells in seven samples and as empty (dead) cells in two of 103 samples $\left(58^{\circ}-59^{\circ} \mathrm{S}, 40^{\circ}-48^{\circ} \mathrm{W}\right.$; T. K. Ashworth, pers. comm., 1989). At the 14 stations in the Weddell Sea study, it was present at six. In the surface sediments, it averaged approximately $0.3 \%$ of the diatom valves in Prydz

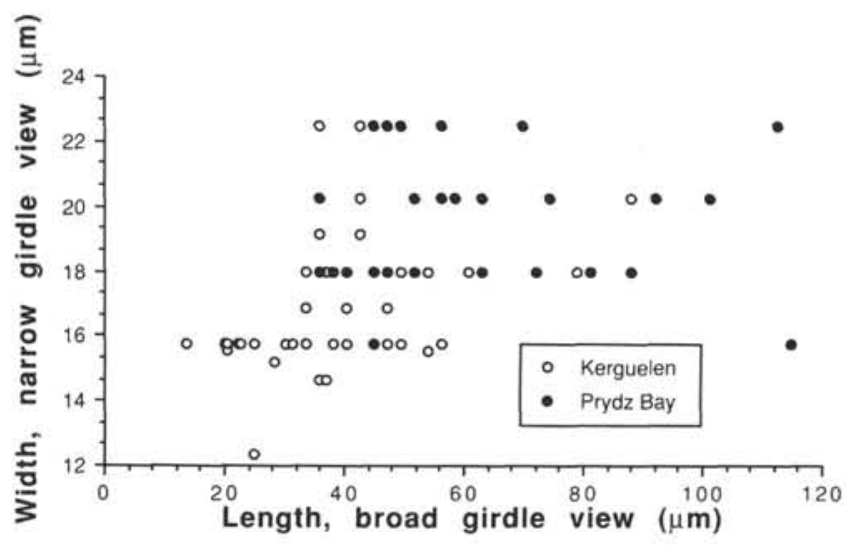

Figure 2. Length of bipolar valves in broad girdle view plotted against width of narrow girdle view for valves seen in valve view from northern (Kerguelen) and southern (Prydz Bay) sediments.
A

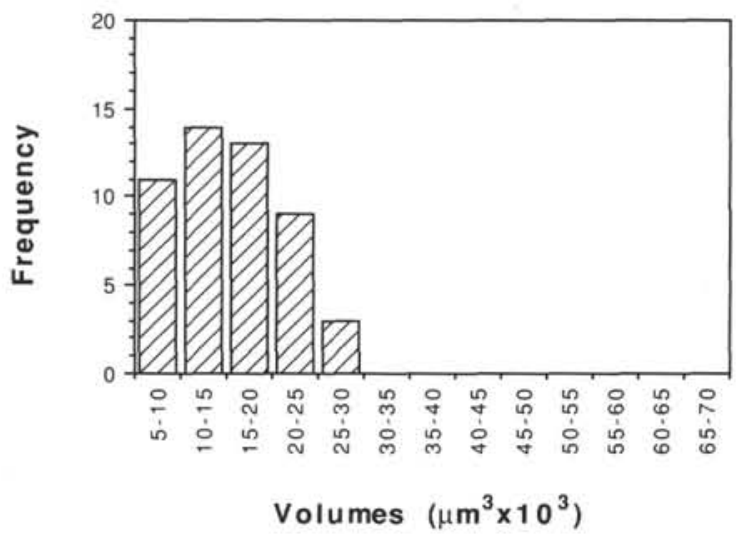

B

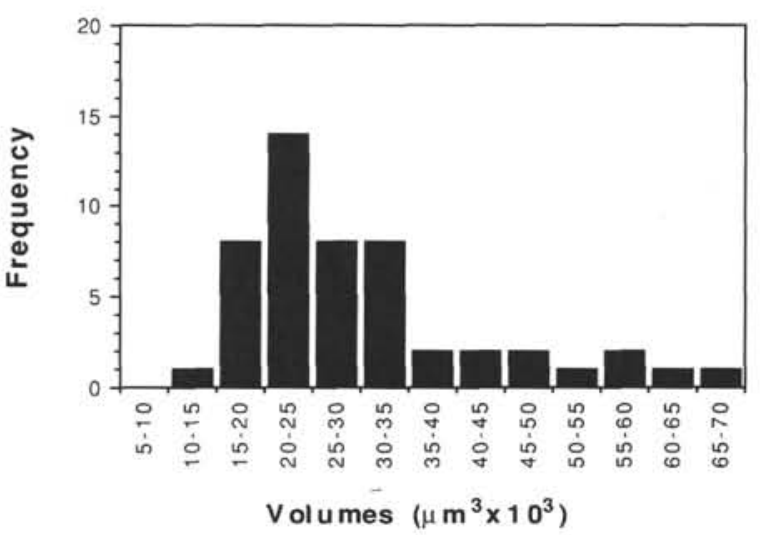

C

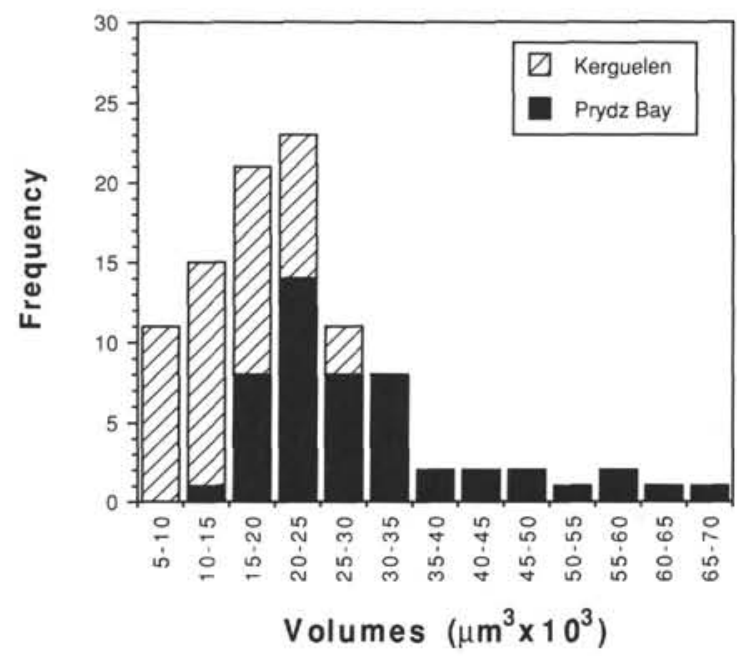

Figure 3. Cell volumes estimated from dimensions of valves from sediment. A. Kerguelen $(n=50)$. B. Prydz Bay $(n=50)$. C. Stacked bar graph with northern and southern populations.

Bay. Although it is not dominant in the plankton or the sediments, it is significant in that it is often well preserved in sediments, is easily recognized, and carries a clear biological message in the index of the ratio of intercalary to terminal valves.

The evidence of the growth habit of Eucampia antarctica var. antarctica in plankton over the Kerguelen Plateau supports the observations of Fryxell and Prasad (1990) of Eucampia antarctica var. recta in the Weddell Sea that there is no development of resting spores in either variety of this species, but instead a 


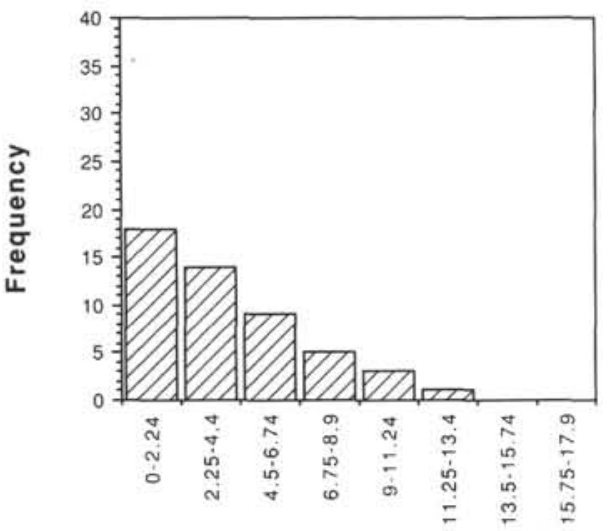

Difference in heights $(\mu \mathrm{m})$

B

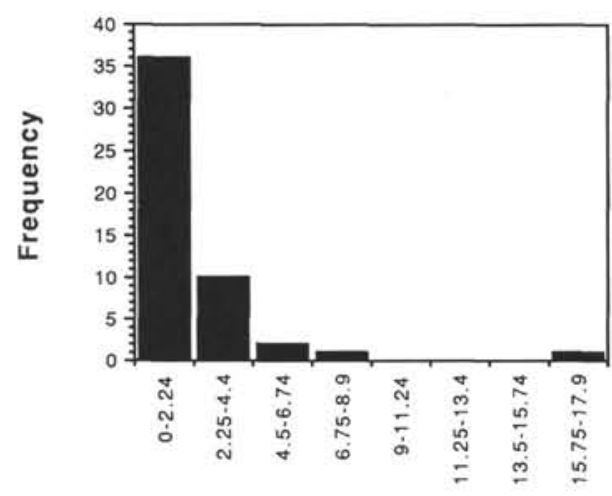

Difference in heights $(\mu \mathrm{m})$

\section{C}

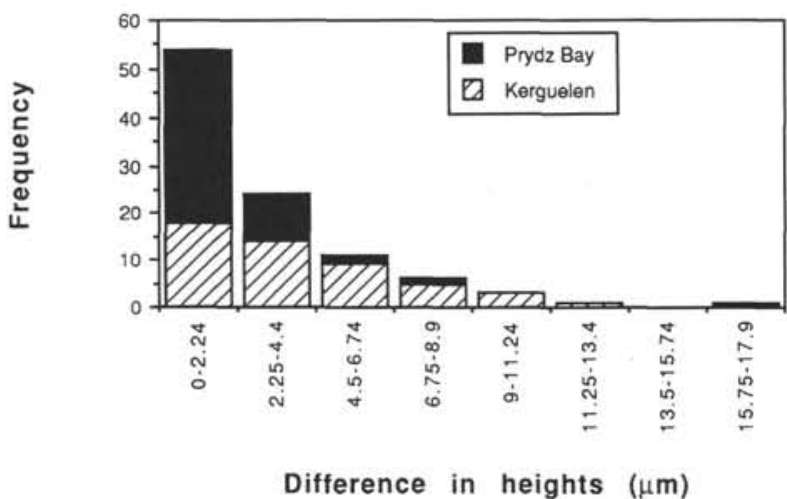

Figure 4. Differences in heights of elevations measured on one valve from sediment. A. Kerguelen $(n=50)$. B. Prydz Bay $(n=50)$. C. Stacked bar graph with northern and southern populations.

winter growth stage in each case. The long chains of heavily silicified cells seen in the plankton at the subpolar sites can be explained by division of the original heavily silicified doublets formed when the winter stage is triggered and the summer vegetative theca thrown off. The chains are usually shorter in the polar variety, perhaps in part because there are no small, flattened spines to aid in bracing the elevations against separating forces. In each variety, the winter growth stage is not only more heavily silicified but different morphologically from the summer vegetative stage.
Because the terminal valves of the original doublets of the winter stage can be distinguished from the intercalary valves, it is possible to estimate the average number of doublings of the population represented in one sample. For instance, the Prydz Bay sample shows a ratio of $177 / 381$, or about $1 / 2$, giving about 0.5 divisions of the winter stage averaged over the years represented by the sample (Table 2 ). These are probably the extreme conditions for survival of E. antarctica var. recta, with only a few weeks of an ice-free window in Prydz Bay. Thus, after the winter stage is triggered (as was seen repeatedly in the plankton of Prydz Bay), only one division for every two cells could be expected before the ice goes out in the spring, assuming the gyre keeps the cells in the bay area. Augmenting this number is the death of the spore-forming cells, because they start out with two intercalary valves from the first mitotic division (Fryxell and Prasad, 1990).

In contrast, the ratio of terminal valves to the intercalary valves of $E$. antarctica var. antarctica from the north Kerguelen Plateau is $6 / 571$, or $1 / 95$, which indicates about 6.5 divisions during the winter stage when turbulent mixing is at its maximum and light is at its minimum. That figure may well be the maximum division rate that can be expected during the season with no ice cover. The summer vegetative stage is usually not well represented in the sediment, but the long chains found in net hauls indicate that many divisions take place.

Although the winter stage of $E$. antarctica is not a resting spore, few polar diatoms have true resting spores, compared with those in temperate waters (Hargraves and French, 1983). Chaetoceros, Odontella, Thalassiosira, and Porosira resting spores were seen during Leg 119 (G. A. Fryxell, unpubl. data; D. A. Stockwell, pers. comm., 1988). They represent two, and possibly three, different structures of spores: the Chaetoceros spore is the simplest with two valves and no bands, the Odontella spore has one large band with two valves differing from the vegetative valves, and Thalassiosira and Porosira spores resemble modified, heavily silicified vegetative cells with a minimal complement of bands. None of these spores, however, reproduces itself, but it germinates into the vegetative stage. Syvertsen and Hasle (1983) pointed out that resting spores are not found in other species in the genus Eucampia. Eucampia antarctica has developed a winter life stage that reproduces itself until the summer vegetative stage is again triggered by the return of light. The resulting growth index can prove a useful tool in understanding the ecological conditions in any one stratum.

In addition, the basic differences not only in the structure of the resting spores but also in the manner of protection of the gene pool during the months of low light and ice cover suggest that resting spore formation is not a character inherited from a common ancestor by diatoms. Other heavily silicified antarctic diatoms may prove to be winter stages, as well.

The morphology of the winter stage shows the same kind of relationship of the valves as seen in the temperate coastal diatom Skeletonema costatum Cleve (Housley et al., 1975) in that the valves abut directly with the girdle bands overlapping the hypovalve until cell division. The bands themselves are diaphanous in both cases, in contrast to the more heavily silicified valves (Fryxell, 1976). Cells made in this way have a strengthened external structure, almost sporelike, during periods of no division.

Although the sexual cycle has not been observed, the postauxospore valves of maximum size with sloping distal portions of elevations have been noted (G. A. Fryxell, unpubl. data) during the austral summer in Prydz Bay. The auxospore may be a delicate stage that does not usually survive collection procedures, but delicate cells of maximum size are produced. Valve morphogenesis, as in other diatoms, takes place inside the girdle bands and not inside the parent valves. Thus, the delicate nature 
of the Eucampia bands would not require much reduction of size with each generation, especially in certain ranges.

Although the taxonomic separation of the polar and subpolar varieties is supported by the present study, it is apparent that there is little morphological separation (Figs. 1-4), and there may still be some mixing of the gene pools with the waxing and waning of the polar ice. In each case, the combined measurements could be interpreted as forming a continuum.

The continuing problem involving the size distribution of the two varieties possibly carries another message. The Kerguelen size distribution appears to be complete, as if the complete size cycle was recorded (Fig. 1A), whereas that from Prydz Bay seems truncated in midrange, or at any rate extended in the upper range (Fig. 1B). One possible explanation is that in Prydz Bay smaller cells may not have enough reserves to last through the long, dark winter. Another explanation is that if one assumes that the sexual cycle is triggered in the early austral spring from the cells of the smaller sizes, a complete sexual cycle might be completed each year in the subpolar Kerguelen area because of the number of cell divisions in one clone and accompanying size reduction. But in the Prydz Bay population, several years may pass between sequential auxospore productions, and the slower division rate may result in a number of smaller cells ready for auxospore production long before the short window of ice-free conditions occurs. The reduction of size may be slightly more rapid for the heavily silicified winter stage in spite of the diaphanous cingulum, and the polar variety must stay in the winter stage several months longer than the subpolar.

The presence of two varieties explains the reported bimodal distribution of $E$. antarctica in the plankton, as well as in the sediments, without transport by AABW. Even if the ACZ is assumed to form a dynamic boundary between populations of $E$. antarctica var. antarctica and E. antarctica var. recta, another distribution problem deals with the variation of the sediments that is related to the movements of the ACZ and the meanders north and south, sometimes resulting in warm and cold core rings that transport plankton out of their preferred habitat. Additional study is needed to understand the sedimentary record at this polar boundary, and the ratio of the two varieties can provide much further information.

\section{CONCLUSIONS}

Eucampia antarctica var. antarctica is found north of the ACZ over the Kerguelen Plateau. Eucampia antarctica var. recta is an austral polar taxon, found south of the ACZ, near the ice edge in the Weddell Sea and near the continent in Prydz Bay. Each variety forms a winter stage, well preserved in sediments, that differs in the degree of silicification and in morphology from its rapidly growing summer vegetative stage. The winter stage provides evidence of parallel evolution of cells that function as spores and suggests that the production of resting spores may not be a primitive character in diatoms but may be secondarily derived. The chains of the winter stage originally consisted of doublet cells with a total of two terminal and two intercalary valves. No more terminal cells are produced, and thus the ratio of terminal to intercalary valves provides an index that can be used to record average winter growth in one stratum, indicating an average of more than six divisions in the Kerguelen area and less than one division in Prydz Bay.

\section{ACKNOWLEDGMENTS}

I thank T. K. Ashworth for the phytoplankton cell counts from the AMERIEZ 88 Winter Cruise and N. Mufti for plate preparation and technical assistance. D. Valencic aided with the microscopic analysis and measurements. S. P. Gonzales provided many of the calculations and graphics. I appreciate conversations with J. G. Baldauf, A.K.S.K. Prasad, and D. A.
Stockwell, who contributed to the ideas presented here, and samples generously shared by S. Z. El-Sayed. Partial support was received from National Science Foundation grant DPP 8418850 , supplemented by NSF Research Experience for Undergraduates (REU) Awards, and the Ocean Drilling Program supported my participation as a biologist on Leg 119, plus Grant P.O. 20200. Early drafts of the manuscript were read critically by P. A. Fryxell.

\section{REFERENCES}

Abbott, W. H., 1974. Temporal and spatial distribution of Pleistocene diatoms from the southeast Indian Ocean. Nova Hedwigia Beih., 25:291-346.

Battarbee, R. W., 1973. A new method for the estimation of absolute microfossil numbers, with reference especially to diatoms. Limnol. Oceanogr., 18:647-653.

Burckle, L. H., 1984. Ecology and paleoecology of the marine diatom Eucampia antarctica (Castracane) Manguine. Mar. Micropaleontol., 9:77-86.

Burckle, L. H., and Stanton, D., 1975. Distribution of displaced Antarctic diatoms in the Argentine Basin. Nova Hedwigia Beih., 53: 283-292.

DeFelice, D. F., and Wise, S. W., Jr., 1981. Surface lithofacies, biofacies, and diatom diversity patterns as models for delineation of climatic change in the southeast Atlantic Ocean. Mar. Micropaleontol., 6:29-70.

Ehrenberg, C. G., 1844. Einige vorlaufige resultate seiner untersuchungen der ihm von der Südpolreise des Capitain Ross, so wie von der Herren Schayer und Darwin zugekommenen materialien über das verhalten des kleinsten lebens in den oceanen und den grossten bisher zuganglichen Tiefen des Weltmeers vor. Ber. Bekanntm. Verh. Königl. Preuss, Akad. Wiss. Berlin, (1844):182-207.

Fenner, J., 1977. Cenozoic diatom biostratigraphy of the equatorial and southern Atlantic Ocean. In Perch-Nielsen, K., Supko, P. R., et al., Init. Repts. DSDP, 39: Washington (U.S. Govt. Printing Office), 491-623.

Fenner, J., Schrader, H. J., and Wienigk, H., 1976. Diatom phytoplankton studies in the southern Pacific Ocean, composition and correlation to the Antarctic Convergence and its paleoecological significance. In Hollister, C. D., Craddock, C., et al., Init. Repts. DSDP, 35: Washington (U.S. Govt. Printing Office), 757-813.

Fryxell, G. A., 1976. The position of the labiate process in the diatom genus Skeletonema. Br. Phycol. J., 11:93-99.

1989. Marine phytoplankton at the Weddell Sea ice edge: seasonal changes at the specific level. Polar Biol., 10:1-18.

Fryxell, G. A., and Prasad, A.K.S.K., 1990. Eucampia antarctica var. recta (Mangin) stat. nov. (Biddulphiaceae, Bacillariophyceae): life stages at the Weddell Sea ice edge. Phycologia, 29:27-38.

Fryxell, G. A., Prasad, A.K.S.K., and Fryxell, P. A., 1989. Eucampia antarctica (Castracane) Mangin (Bacillariophyta): complex nomenclature and taxonomic history. Taxon, 28:638-640.

Gombos, A. M., Jr., 1974. Diatoms as indicators of Antarctic interglacials. In Symposium on Marine Plankton and Sediments and Third Planktonic Conference, Kiel, Abstracts, 27.

1976. Paleogene and Neogene diatoms from the Falkland Plateau and Malvinas Outer Basin: Leg 36, Deep Sea Drilling Project. In Barker, P. F., Dalziel, I.W.D., et al., Init. Repts. DSDP, 36: Washington (U.S. Govt. Printing Office), 575-687.

Hargraves, P. E., 1968. Species distribution and composition of net plankton diatoms in the Pacific sector of the Antarctic Ocean [Ph.D. dissert.]. Coll. William and Mary, Virginia.

Hargraves, P. E., and French, F. W., 1983. Diatom resting spores: significance and strategies. In Fryxell, G. A. (Ed.), Survival Strategies of the Algae: Cambridge (Cambridge Univ. Press), 49-68.

Hasle, G. R., 1969. An analysis of the phytoplankton of the Pacific Southern Ocean: abundance, composition, and distribution during the Brategg Expedition, 1947-1948. Hvalradets Skr., 52:1-168.

Hasle, G. R., von Stosch, H. A., and Syvertsen, E. E., 1983. Cymatosiraceae, a new diatom family. Bacillaria, 6:9-156.

Housley, H. L., Scheetz, R. W., and Pessoney, G. F., 1975. Filament formation in the diatom Skeletonema costatum. Protoplasma, 86: 363-369.

Hustedt, F., 1958. Diatomeen aus der Antarktis und dem Südatlantik. Dtsch. Antarkt. Exped. 1938-1939, 2:1-191. 
Kang, S.-H., 1989. Diatom species composition and abundance in water column assemblages from five drill sites in Prydz Bay, Antarctica, Ocean Drilling Program Leg 119: distributional patterns [M.S. thesis]. Texas A\&M Univ., College Station, TX.

Kozlova, O. G., 1966. Diatoms of the Indian and Pacific Sectors of the Antarctic: Jerusalem (S. Monson).

Krebs, W. N., 1977. Ecology and preservation of neritic marine diatoms, Arthur Harbor, Antarctica [Ph.D. dissert.]. Univ. California, Davis.

, 1983. Ecology of neritic marine diatoms, Arthur Harbor, Antarctica. Micropaleontology, 29:267-297.

Ross, R., Sims, P. A., and Hasle, G. R., 1977. Observations on some species of the Hemiauloideae. Nova Hedwigia Beih., 54:179-213.

Schrader, H. J., 1976. Cenozoic planktonic diatom biostratigraphy of the southern Pacific Ocean. In Hollister, C. D., Craddock, C., et al., Init. Repts. DSDP, 35: Washington (U.S. Govt. Printing Office), 605-671.
Semina, H. J., 1982. Morphology of the frustula of Eucampia balaustium Castr. (Bacillariophyta, Biddulphiaceae). Trans. P. P. Shirshov Inst. Oceanol., 114:20-26.

Sims, P. A., 1986. Sphynctolethus Hanna, Ailuretta gen. nov., and evolutionary trends within the Hemiauloideae. Diatom Res., 1:241-269.

Steyaert, J., 1973. Distribution of plankton diatoms along an AfricanAntarctic transect. Inv. Pesq., 37:295-328.

Steyaert, J., and Bailleux, E. M., 1975. Eucampia balaustium Castr. and Molleria antarctica Castr--taxonomy and nomenclature. Microscopy, 32:461-470.

Syvertsen, E. E., and Hasle, G. R., 1983. The diatom genus Eucampia: morphology and taxonomy. Bacillaria, 6:169-210.

Date of initial receipt: 18 September 1989

Date of acceptance: 4 December 1989

Ms 119B-139 


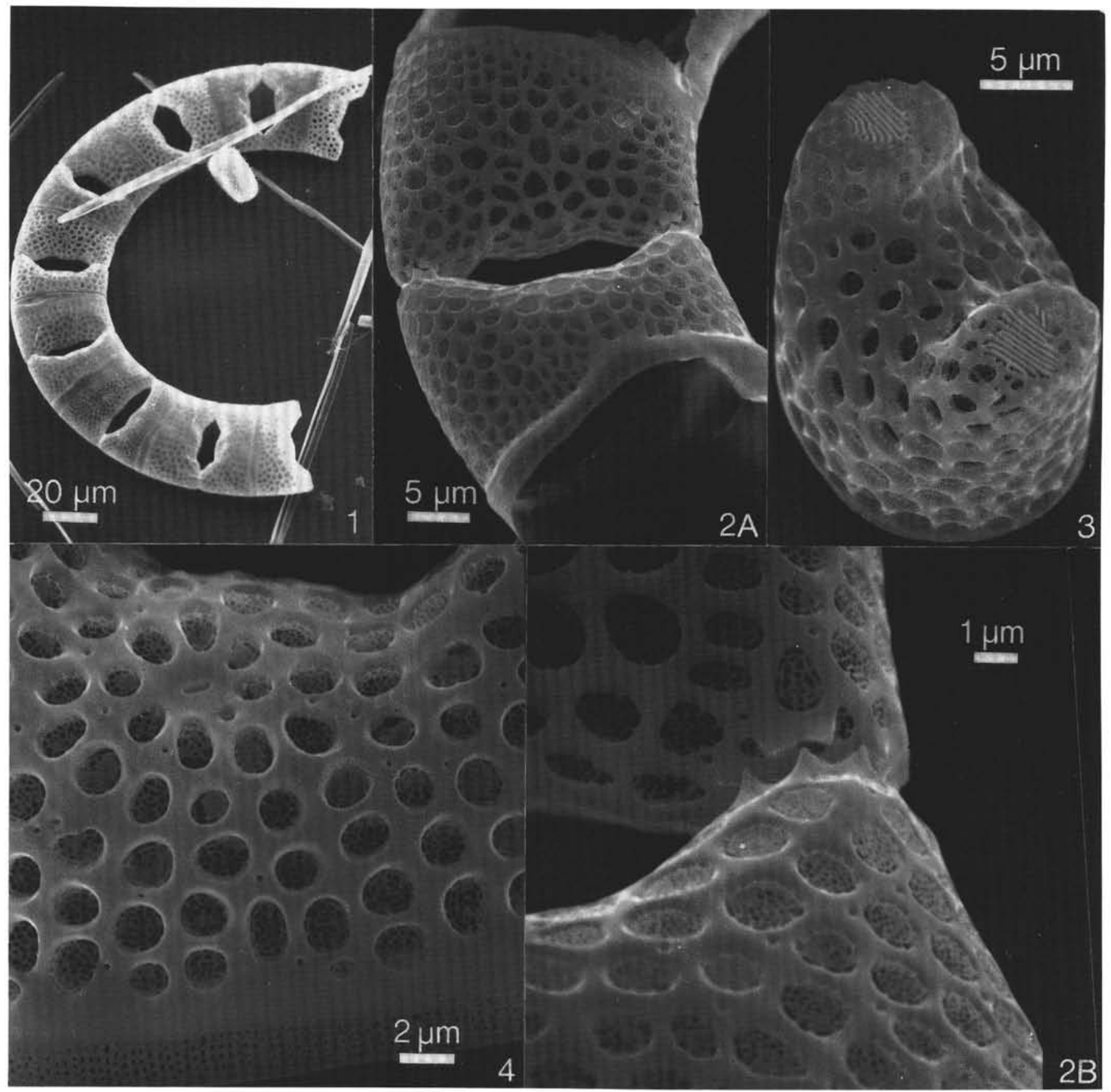

Plate 1. SEM photomicrographs of Eucampia antarctica var. antarctica, winter stage, collected with a hand-held 20- $\mu \mathrm{m}$ net deployed in thruster effluent at ODP Hole 736C, 29 December 1987. 1. Spiraling chain. Note flattened elevations of cells and the thin cingulum bands covering hypothecae. 2. A. Sibling valves with portions of bands still attached. B. Detail of same specimen showing flattened spines, augmenting organic material extruded from the pore fields serving to connect sibling valves. 3. Oblique view of valve showing raised costae of the pore fields. 4. Ventral view of valve with external slit of labiate process with rows of areolae radiating from it, located approximately five areolae from the margin with band still attached. 


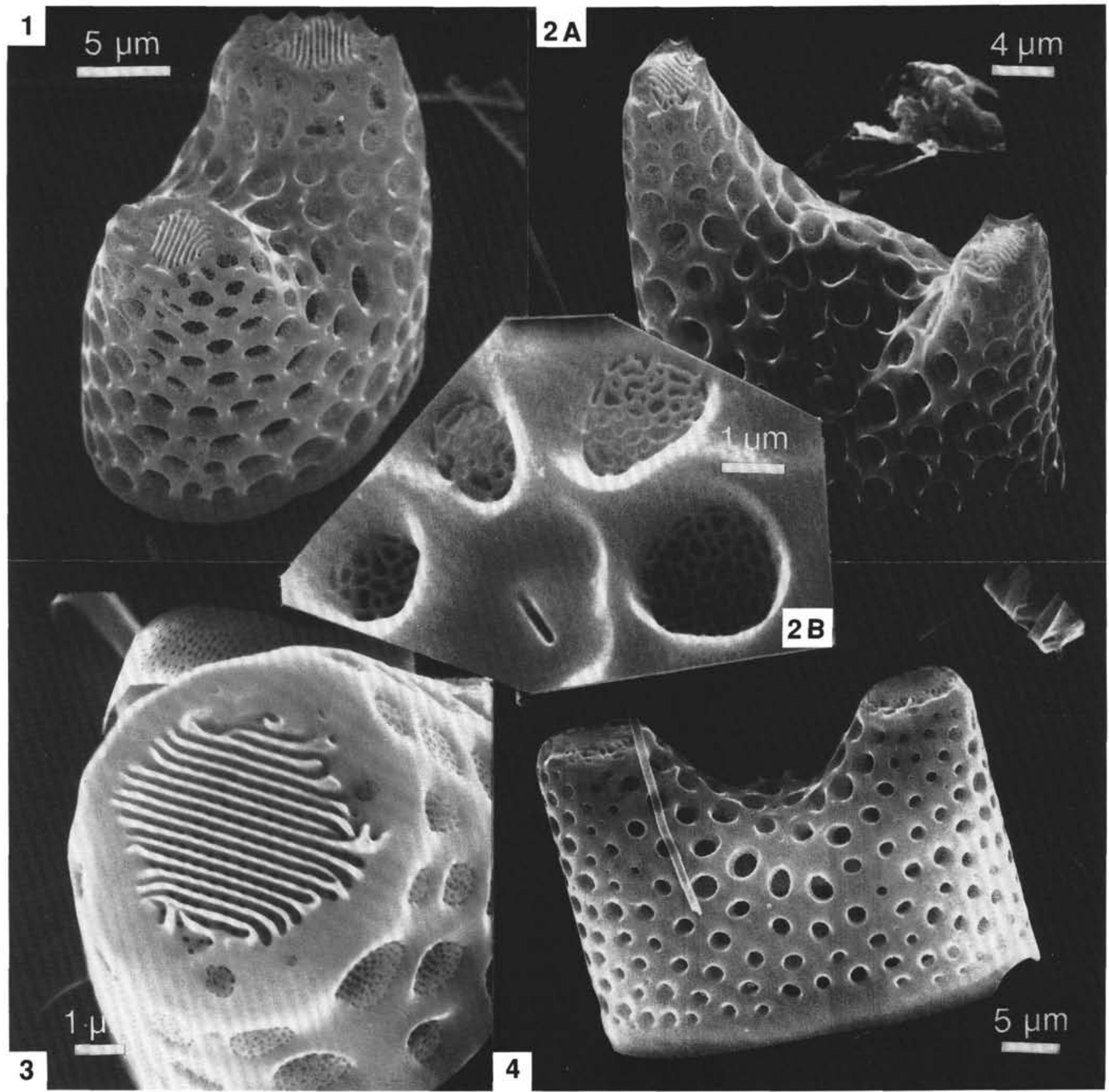

Plate 2. SEM photomicrographs of a comparison of winter stages of Eucampia antarctica var. antarctica with Eucampia antarctica var. recta. 1. E. antarctica var. antarctica, same as Plate 1, oblique view of valve showing spine formation and heavy silicification. 2. A. E. antarctica var. antarctica, from a $35-\mu \mathrm{m}$ net haul, Eltanin Cruise 46 , Station $17 \mathrm{H}, 49^{\circ} 22^{\prime} \mathrm{S}, 70^{\circ} 43^{\prime} \mathrm{E}, 10 \mathrm{March} 1975$. B. Detail of same specimen showing external slit of labiate process with surrounding areolae capped with delicate, irregular cribra. 3. E. antarctica var. recta, from 35- $\mu \mathrm{m}$ net haul, cleaned of organic matter, Weddell Sea Bio-Cruise, Station K-L, $74^{\circ} 08^{\prime}$ S, $41^{\circ} 32^{\prime}$ S, 25 February 1977 . Detail of ridged pore field surrounded by heavily silicified hyaline ridge, forming a costate ocellus. Areolae with sublinear array of pores in cribra. 4. E. antarctica var. recta, from 35- $\mu \mathrm{m}$ net haul, rinsed of salts, Weddell Sea Bio-Cruise, Station K, $73^{\circ} 07^{\prime} \mathrm{S}, 42^{\circ} 44^{\prime} \mathrm{W}$. Broad girdle view showing characteristic outline. 


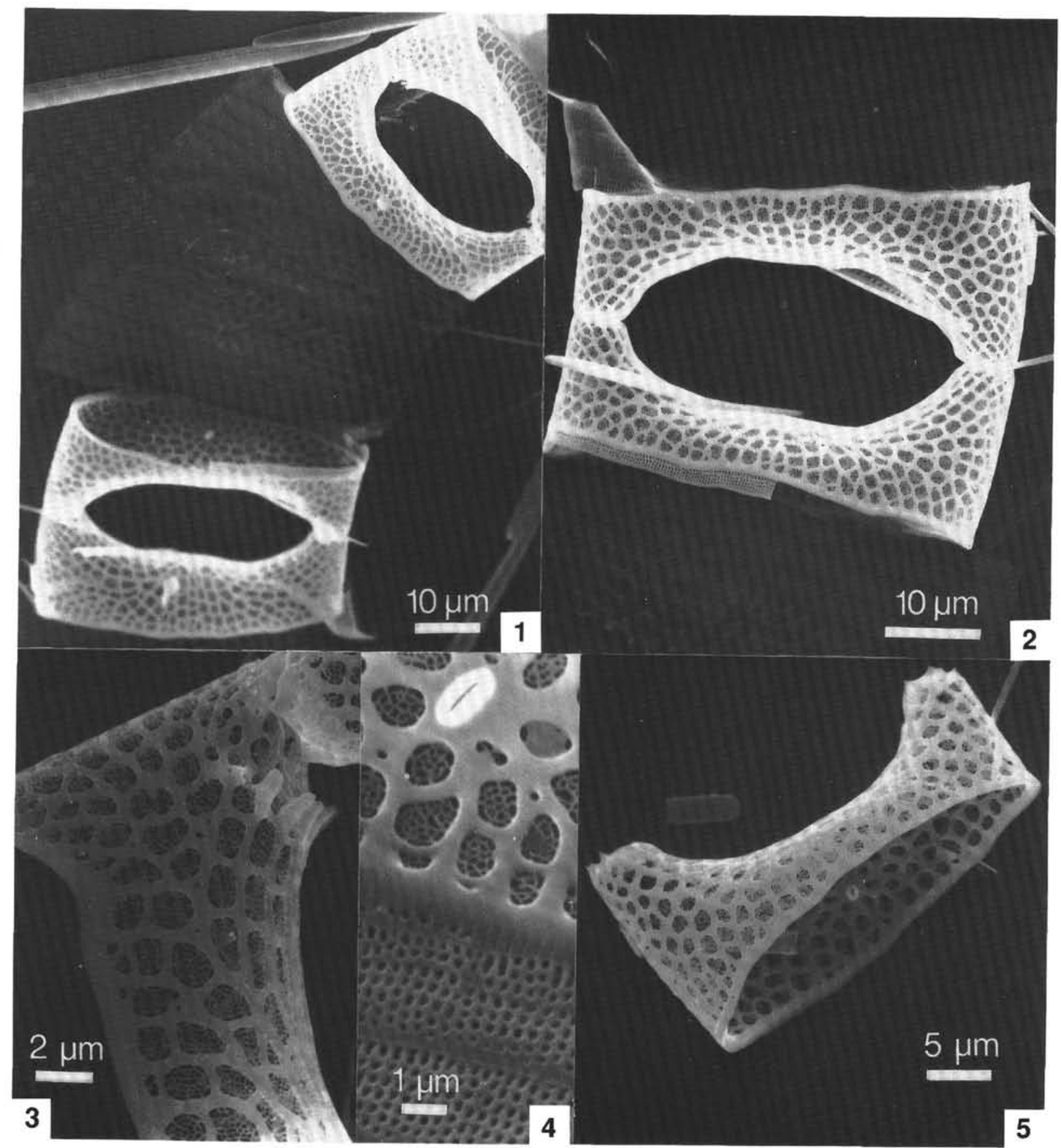

Plate 3. SEM photomicrographs of Eucampia antarctica var. antarctica, summer vegetative stage, collected with a hand-held $20-\mu \mathrm{m}$ net deployed in thruster effluent, ODP Hole 736C, 29 December 1987. 1. Summer vegetative cell dried on stub in chain curved in broad girdle view. New valves are forming in mature sets of bands of epitheca and hypotheca. 2. Sibling valves showing characteristics of variety of asymmetry and relatively straight margins with fragments of delicate bands attached. 3. Detail of abnormal valve with spine formation from walls between areolae, showing development possibly from contact with sibling valve at one stage in morphogenesis. 4. Detail of valve showing internal labiate process two areolae from margin and fine structure of irregular cribra in contrast to bands with linear arrangement of pores. 5. Oblique view of valve showing internal view of labiate process two areolae from margin and outline of spines on elevation. 


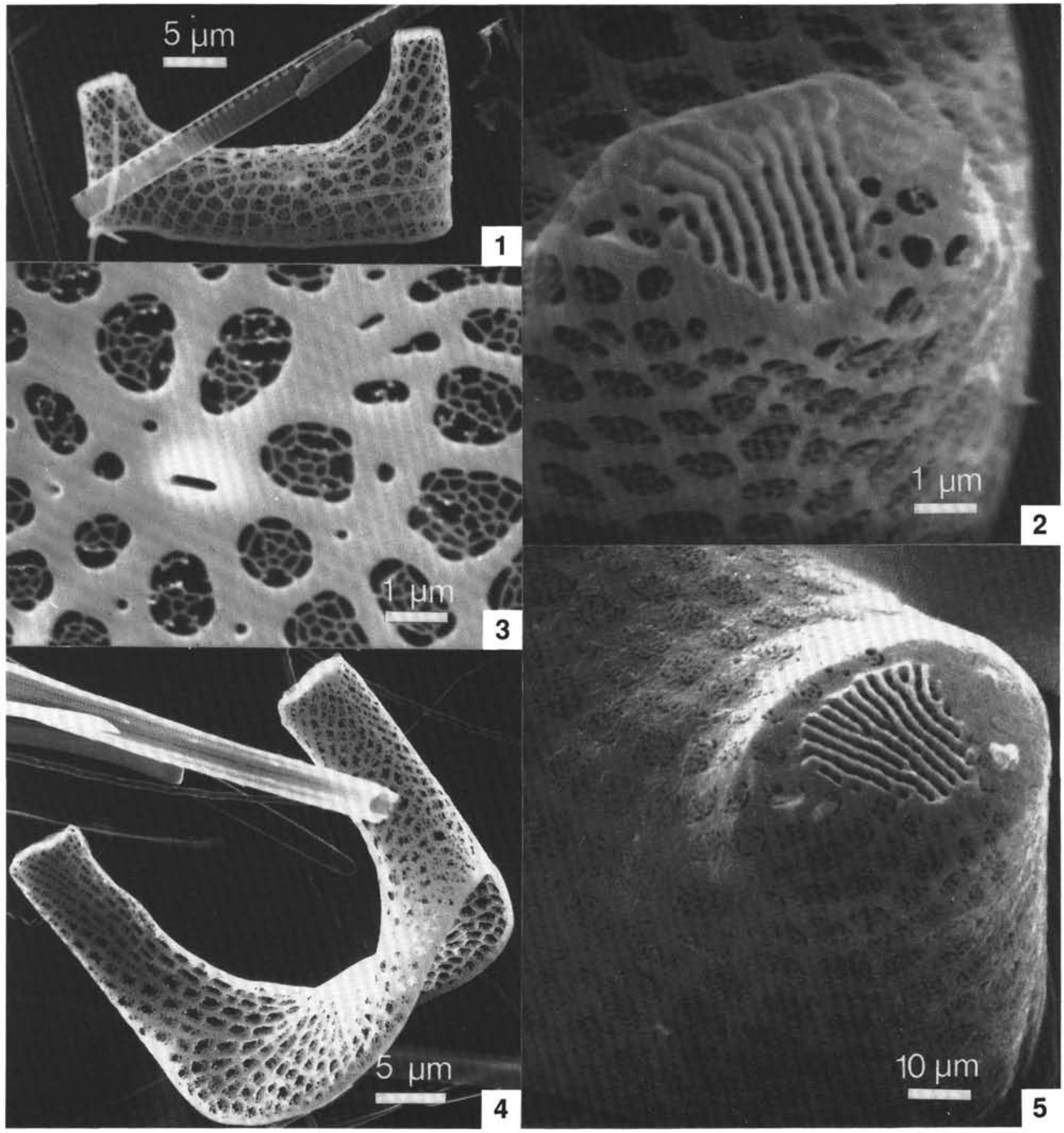

Plate 4. SEM photomicrographs of a comparison of summer vegetative stages of Eucampia antarctica var. antarctica with Eucampia antarctica var. recta. 1-3. E. antarctica var. antarctica, collected with a hand-held $20-\mu \mathrm{m}$ mesh net deployed in thruster effluent, ODP Hole $736 \mathrm{C}, 29 \mathrm{December}$ 1987. Fig. 1. Broad girdle view showing asymmetry of valve with elevations of different heights, polygonal walls of areolae, and nearly straight margin. Fig. 2. Detail of ridged pore field with spine on right. Fig. 3. Detail of external slit of labiate process showing broken cribra. 4. Eucampia antarctica var. recta, from $35-\mu \mathrm{m}$ net haul, Weddell Sea Bio-Cruise, Station K-L, $74^{\circ} 08^{\prime} \mathrm{S}, 41^{\circ} 32^{\prime} \mathrm{W}, 25$ February 1977 . Summer vegetative valve with elevations of equal height, no spines, and marginal line that rises under each elevation. 5. Eucampia antarctica var. recta, from $35-\mu \mathrm{m}$ net haul, Eltanin Cruise 46, Station 9V, $64^{\circ} 32^{\prime} \mathrm{S}, 104^{\circ} 42^{\prime} \mathrm{E}, 15$ December 1970. Detail of ridged pore field on elevation. Note smooth lines of areolae approaching the pore field devoid of spines. 